ISSN 2693-2504

\title{
Myoglobin, Muscle Strength and Elderly Fall-Associated Nutrition
}

Journal of Bioscience \& Biomedical Engineering

Editorial

Attapon Cheepsattayakorn ${ }^{1,2^{*}}$, Ruangrong Cheepsattayakorn ${ }^{3}$ and Nutthanit Teantunyakij ${ }^{4}$

${ }^{1} 10^{\text {th }}$ Zonal Tuberculosis and Chest Disease Center, Chiang Mai, Thailand

${ }^{2}$ Faculty of Medicine, Western University, Pathumtani, Thailand

${ }^{3}$ Department of Pathology, Faculty of Medicine, Chiang Mai University, Chiang Mai, Thailand

${ }^{4}$ The Prince Royal's College (M.6), Chiang Mai, Thailand

The involuntary loss of muscle mass, strength, and function or "sarcopenia" is one of the most prominent effects of aging process [1-3]. Approximately, muscle mass reduces 3-8 \% per 10 years after the age of 30 and this rate increases after the age of $60[4,5]$. These changes are the fundamental causes of disability in the elderly and functional dependence [6,7]. These changes are also associated with a progressive increase in fat mass, changes in body composition, bone density decreases (osteoporosis), kyphosis, joint stiffness increases, an increased incidence of insulin resistance in the elderly, obesity, and heart disease $[1,4,5,8]$. Impact-absorbing flooring, an example of preventive medicine trials could reduce the relative risk (RR) of injury due to fall in elderly by $59 \%$ in a nursing home [9] . Sarcopenia or low muscle mass could be defined as age-associated lean tissue mass loss [10]. Racial and geographical differences should be included in the consideration of the prevalence of sarcopenia, in addition to the reference cut-off thresholds for calf circumference and muscle mass [11]. Sarcopenia was recently defined by using the Asian Working Group consensus algorithm, adjusted by age and gender, in combination with muscle mass, grip strength, and gait speed [12]. Low muscle strength is associated with poor physical function in older male and female persons [13]. Physical function and walking ability are correlated with hand grip strength $[14,15]$. Grip strength, a simple and inexpensive test is positively associated with nutritional health measurement [16] and can predict future falls and fractures in the elderly $[16,17]$.

Lam et al reported that whey protein supplements (WPS) had significantly overall increased the level of branched-chain amino acids level by $458.57 \mathrm{nmol} / \mathrm{L}\left(\mathrm{CI}=179.96,737.18 ; \mathrm{I}^{2}=100\right.$ $\% ; \mathrm{p}=0.00)$ and level of essential amino acids by $624.03 \mathrm{nmo-}$ $1 / \mathrm{L}\left(\mathrm{CI}=169.27,1078.8 ; \mathrm{I}^{2}=100 \% ; \mathrm{p}=0.00\right)$ compared to the control group, wherejbas WPS had decreased myoglobin level by $11.74 \mathrm{ng} / \mathrm{ml}\left(\mathrm{CI}=-30.24,6.76 ; \mathrm{I}^{2}=79.6 \% ; \mathrm{p}=0.007\right)$ and creatinine kinase level by $47.05 \mathrm{U} / \mathrm{L}\left(\mathrm{CI}=-129.47,35.37 ; \mathrm{I}^{2}=\right.$ $98.4 \% ; p=0.000)$ [18]. Recently, Carlsson et al demonstrated their success in production of human myoglobin, a heme-protein in muscle with important functions in tissue oxygenation

\section{*Correspondence authors}

\section{Attapon Cheepsattayakorn}

$10^{\text {th }}$ Zonal Tuberculosis and Chest Disease Center

143 Sridornchai Road

Changklan

Muang

Chiang Mai, 50100

Thailand

Submitted : 26 Jun 2021 ; Published : 9 Jul 2021

and as a regulator in nitric oxide signaling from the leaves of Nicotiana benthamiana by transient expression using a viral vector delivered by Agrobacterium tumefaciens[19].

In conclusion, sarcopenia, a multifactorial factor that predispose to disability and may be prevented and treated modified lifestyle and pharmacological interventions. Plants could be a useful production for myoglobin for potential future nutritional or medical application. Whey protein supplements could be positively ergogenic in supports of myoglobin, creatinine kinase, and amino acids levels in humans.

\section{References}

1. Evans WJ (1995) What is sarcopenia ? J Geron A Biol Sci Med Sci 1995; 50: 5-8.

2. Lexell J (1995) Human aging, muscle mass, and fiber type composition. J Gerontol A Biol Sci Med Sci 1995; 50: 1116.

3. Roubenoff R, Castaneda C (2001) Sarcopenia: understanding the dynamics of aging muscle. JAMA 2001; 286: 1230-1231.

4. Holloszy JO (2000) The biology of aging. Mayo Clin Proc 2000; 75 (Suppl): S3-S8.

5. Melton LJ III, Khosla S, Crowson CS, et al. (2000) Epidemiology of sarcopenia. J Am Geriatr Soc 2000; 48: 625630.

6. Wolfson L, Judge J, Whipple R, King M (1995) Strength is a major factor in balance, gait, and the occurrence of falls. J Gerontol A Biol Sci Med Sci 1995; 50: 64-67.

7. Tinetti ME, Williams CS (1997) Falls, injuries due to falls, and the risk of admission to a nursing home. $N$ Engl J Med 1997; 337: 1297-1284.

8. Dutta C, Hadley EC (1995) The significance of sarcopenia in the old age. J Gerontol A Biol Sci Med Sci 1995; 50: $1-4$.

9. Gustavsson J, Bonander C, Andersson R, Nilson F (2015) Investigating the fall-injury reducing effect of impact absorbing flooring among female nursing home residents : initial results. Inj Prev 2015; 21: 320-324. 
10. Gray M, Glenn JM, Binns A (2016) Predicting sarcopenia from functional measures among community-dwelling older adults. Age 2016; 38: 22.

11. Bahat G, Tufan A, Tufan F, Kilic C, Akpinar TS, Kose M, et al. (2016) Cut-off points to identify sarcopenia according to European Working Group on Sarcopenia in Older People (EWGSOP) definition. Clin Nutr 2016; 35: 15571563.

12. Jang IY, Jung HW, Lee CK, Yu SS, Lee YS, Lee E (2018) Comparison of predictive values of sarcopenia with different muscle mass indices in Korean rural older adults: a longitudinal analysis of the aging study of Pyeong Chang rural area. Clin Interv Aging 2018; 13: 91-99.

13. Visser M, Deeg DJ, Lips P, Harris TB, Bouter LM (2000) Skeletal muscle mass and muscle strength in relation to lower-extremity performance in older men and women. $J$ Am Geriatr Soc 2000; 48: 381-386.

14. Lino VT, Rodrigues NC, O’Dwyer G, Andrade MK, Mattos IE, Portela MC (2016) Handgrip strength and factors associated in poor elderly assisted at a primary care unit in Rio de Janeiro, Brazil. PLoS One 2016; 11: e0166373.

15. Beseler MR, Rubio C, Duarte E, Herva's D, Guevara MC, Giner-Pascual M, et al. (2014) Clinical effectiveness of grip strength in predicting ambulation of elderly inpatients. Clin Interv Aging 2014; 9: 1873-1877.

16. Miller MD, Giles LC, Crotty M, Harrison JE, Andrews GR (2003) A clinically relevant criterion for grip strength: relationship with falling in a sample of older adults. Nutr Diet 2003; 60: 248-252.

17. Balogun S, Winzenberg T, Wills K, Scott D, Jones G, Aitken D, et al. (2017) Prospective associations of low muscle mass and function with 10-year falls risk, incident fracture and mortality in community-dwelling older adults. $J$ Nutr Health Aging 2017; 21: 843-848.

18. Lam FC, Khan TM, Faidah H, Haseeb A, Khan AH (2019) Effectiveness of whey protein supplements on the serum levels of amino acid, creatinine kinase and myoglobin of athletes: a systematic review and meta-analysis. $B M C$ Research 2019; 8: 130. DOI: https ://doi.org/10.1186/ s13643-019-1039-z

19. Carlsson MLR, Kanagarajan S, Bülow L, Zhu LH (2020) Plant-based production of myoglobin-a novel source of the muscle heme-protein. Scientific Reports 2020; 10: 920. DOI : https://oi.org/10.1038/s41598-020-57565-y

Copyright: (C2021 Attapon Cheepsattayakorn. This is an open-access article distributed under the terms of the Creative Commons Attribution License, which permits unrestricted use, distribution, and reproduction in anymedium, provided the original author and source are credited. 